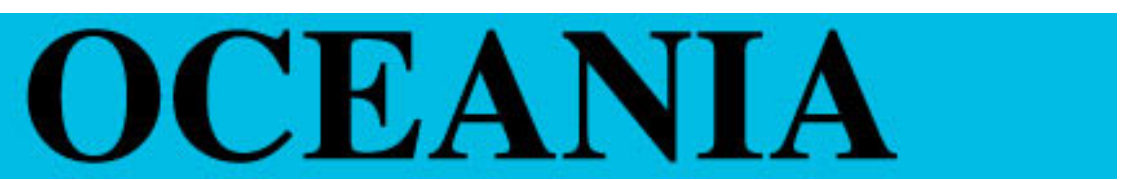

Oceania, Vol. ••, Issue •• (2016): ••-••

DOI:10.1002/ocea.5115

\title{
A Space and Time for a Generation to React: The Gattjirrk Cultural Festival in Milingimbi
}

\author{
Franca Tamisari \\ Ca' Foscari University of Venice \\ and The University of Queensland
}

\begin{abstract}
This article deals with the annually held Gattjirrk Cultural Festival organised in Milingimbi, a Yolngu community in Northeast Arnhem Land, and has the objective of analysing its socio-cultural and political meaning. Although this event is considered an amusement (wakal), it nevertheless constitutes an arena to negotiate postcolonial realities in which Yolngu people are forced to live. Focusing on the organisers' overall frame of 'sharing culture' and youths' interpretations of hip-hop dances as 'performative tactics', I suggest that the Milingimbi Festival creates a space in which generational perspectives within the community as well as the tension between Yolngu people and the non-indigenous (balanda) world may be displayed and mediated. While the Festival has been mainly conceived as a space for encountering and 'sharing culture' with other groups and people both within the community and with the balanda world, it is also seized as an opportunity by young people to generate new ways to engage with and challenge others. By weaving together elements of Yolngu heritage and pop culture, I argue that fun or burlesque dances (wakal bunngul) are 'tactics of cultural remix' that through laughter and irony demand a witnessing: a mutual recognition, engagement, and responsibility to participate and to respond. It is thus in their own ways that these performances produce new connections and relationships bringing together old and young, Yolngu and balanda in an effective although fleeting encounter.
\end{abstract}

Keywords Australian indigenous festival, hip-hop dance performance, Northeast Arnhem Land, performative tactics, cultural remix, 'sharing culture', burlesque.

\section{INTRODUCTION}

Daubed with white paint and clad in the ceremonial loin cloth (naga) as if ready for a ceremonial dance, a group of Yolngu adolescents started moving to the accelerated disco-beat version of the famous Greek popular tune 'Zorba'. Filmed by an audience member, the dance was then posted on YouTube, quickly crossing the community festival boundaries to reach a vastly wider public. From 2007 onwards, this performance gave visibility to a veritable genre of Yolngu 'popular' or 'minor' theatre eventually leading to several national shows across the country and the establishment of a very successful dance company. ${ }^{1}$

Each movement of the reinterpreted Zorba performance refers to precise and wellrecognisable pop culture elements as well as ceremonial dance moves in a simple yet energetic choreography. It is a compelling way for young people to display their interests, experiences, and perspectives both to their elders as well as to non-indigenous people. Michael Jackson side head turns and steps are combined with the foot lifts and feet crossing of Greek dancing, while the stomping of Yolngu male stepping style, the aggressive moves, and arm gestures used in

The Gattjirrk Festival creates a space and time for a generation to react (Keith Lapulung, Milingimbi, 5 June 2014). 
ceremony are suspended with a series of clownish freezes, such as the hip thrusts and wide leg posture depicted in the early images of 'corroborees'. ${ }^{2}$ It is also possible to recognise the Charlie Chaplin walk, women's disco-style dancing, rope skipping, and basketball handling movements. All these elements are kept together by the frantic rhythm of the skipping, shoulder shimmies, puppet-like actions, pelvis thrusts, and bum shakes.

The comic moves of this uncompromisingly provoking and mocking performance well capture the role and significance of the little known Gattjirrk Cultural Festival that, from the beginning of the 1980s to today, has been held annually in Milingimbi, a Yolngu community in Northeast Arnhem Land. ${ }^{3}$ In fact, the performance 'Zorba the Greek Yolngu Style' is not only a synthesis of local youths' different types of dance expression. It is rather a tactic of cultural remix: the practice of weaving together elements of Yolngu heritage and pop culture, the comic and the serious, the high and the low, the old and the new. It is a particular instance in which, through the lightness and permissions of comedy, Yolngu youth display their interests and share their experiences, thus confronting both their elders and non-indigenous people with a critical perspective on race relations and a new political engagement.

In what follows, I will present the organisers' main objectives in staging the Milingimbi Cultural Festival and the opportunity it offers the younger generations to announce both their presence and different ways of being. Although Yolngu people in the community and in the region consider this event as a 'wakal', literally 'play', 'fun', 'amusement', and 'entertainment' (also 'joke', 'facetiousness', and 'fooling around'), it nevertheless constitutes a space to negotiate the postcolonial realities in which Yolngu people are forced to live. As in the past, the event's organisers and older people see the Festival as a way of teaching the younger generations to grow physically and spiritually strong in their own community as well as to teach and 'share Yolngu culture' with white people or balanda. In contrast, mainly through hip-hop and burlesque dance performances, Yolngu adolescents use this space to display and affirm their experiences and different ways of dealing with the ever-changing socio-political and economic challenges they are facing in the present. Turning attention to youth's performances, I suggest that the Gattjirrk Festival opens up a space in which the intergenerational relations within the community as well as the tension between Yolngu people and the balanda world are displayed, mediated, and negotiated. It is in this space that different groups, the young and the old have the potential for formulating new socio-political and aesthetic syntheses that realign individual and community life to historical circumstances in continuing and rapid transformation. As Festival's founder and organiser, Keith Lapulung succinctly put it: 'the Gattjirrk Festival creates a space and time for a generation to react'.

All festivals I attended in Milingimbi from the beginning of the 1990s included rock band performances, a competition among adolescents who choreographed and performed hip-hop items in the breaking or breakdance style, short dances adapted from the ceremonial repertoire, pantomimes staged by elders with educational purposes, Christian songs and so called 'action' dances (see note 14). In all events I attended, 'fun dances' (wakal bunggul) or 'burlesque dances' (doitj and shakim) were also performed mainly by young male dancers who manage to fully capture spectators' attention and make them roar with laughter. Mixing steps and arm movements from different repertoires, these dances constitute a veritable Yolngu popular theatre form (djatpangarri) deployed in ceremonial and everyday contexts to contest the established truth and order thus revealing a particular point of view on colonial history and intergenerational relations from which the world can be seen anew (Bakhtin 1984a:66).

Dance performance can be one of the most codified human practices yet, at the same time, one of the most flexible forms open to interpretation and change, simultaneously an instrument of coercion and resistance, a faithful reproduction of social differences, for instance at national, generational and ethnic levels, but also a way in which these differences are questioned and challenged (Desmond 1993). It can simultaneously be a reflection of 
shared principles and values yet also an arena for statements of difference and autonomy. Within the Festival's overall frame of 'sharing culture' both among Yolngu groups from the region and balanda visitors (including a growing balanda audience via several types of social media and networks), I suggest that Yolngu youths' dance styles are not alone in conveying a host of meanings revealing and concealing the values and principles of a generation and social group within the community. ${ }^{4}$ However, in their more elaborate versions staged by veritable Yolngu jesters (gabulay), such as the 'Zorba the Greek Yolngu Style' dance, these performances may also be politically subversive in redefining the terms of confrontation with dominant non-indigenous values, rules, and institutions.

The ambiguity of burlesque and 'fun dances' lead me first to question the apparently banal and superficial aspects of forms of play and entertainment and closely consider the practice of sampling elements from different repertoires, activities, and life situations to create new compositions. By remixing styles and performance genres, these dances tell their story and, by displaying young people's everyday experiences and aspirations, offer opportunities of 'pure possibility whence novel configurations of ideas and relations may arise' (Turner 1967:97). In Bakhtin's (1984a:34) words, the 'carnivalesque spirit' or the 'carnival sense of the world' (Bakhtin 1984b:107) characterising these performances 'offers a chance outlook on the world, to realize the relative nature of all that exists, and to enter a completely new order of things'. In other words, the political and critical force of youths' dancing stems from the attention they demand and the way they challenge spectators to understand and respond in fleeting yet engaging laughter.

\section{THE MILINGIMBI 'GATTJIRRK CULTURAL FESTIVAL'}

Despite its name, its increasing success and its organisers' unstinting efforts to invite and engage with a growing number of indigenous and non-indigenous visitors and spectators, the Gattjirrk Festival remains however a small-scale event that, like the non-indigenous Australian rural festivals considered by Gibson and Connell (2011:8), is locally oriented and provides a space to display differences and strengthen ties between families, groups, and generations. In addition, as with other small indigenous festivals around the country, up to today, the Milingimbi event has been organised by community people 'without dedicated festival administration or support' ( $c f$. Phipps and Slater 2010:10). The Gattjirrk Festival, however, shares its origin, aims, and vision with the better known and more elaborate Garma Festival annually held since 1999 at Gulkula near Nhulunbuy (see http://www.yyf.com.au/, De Largy Healy 2011; Henry 2008). Further, like other indigenous festivals in Australia, it can be also interpreted as 'a public statement of the continuity of cultural transmission' (Henry 2000a, 2000b:326), a means to retrieve or invent tradition, engage, and make sense of history (Henry 2008:54), a space to celebrate indigenous cultural distinctiveness (Phipps and Slater 2010:19), affirm the 'inalienability of cultural singularities' (Glowczewski 2007:16), and challenges mainstream representations of indigeneity (Slater 2007:580). In addition, as all authors who study this typology of public events in Australia have stressed, the Gattjirrk Festival can also be understood as a political strategy to claim the recognition of indigenous ways of being and their rights in the relationship with the state (Henry 2008:54; Phipps 2011). In this paper, however, I turn my attention to the ways in which the Gattjirrk Festival remains an arena to articulate power relations between local groups in the community, as De Largy Healy (2011) has documented for the Garma Festival, or between men and women, as Tonnaer (2007:97) has argued for the Airplane Dance performance at the Borroloola Festival. From this perspective, I look at the Gattjirrk Festival as a space where the younger generations can display their own particular way of seeing the world and thus enter into a 'performative dialogue' with the older generations as well as with balanda spectators on their own terms (Magowan 2000:318). 
It is important to note that, together with the Garma Festival, the Gattjirrk Festival is only one instance of the several 'rituals' or 'expressions of diplomacy' (Henry 2011:189; Tamisari 2006a:117; Wild 1986) in which Yolngu people have used dance to demand attention and challenge spectators to engage, acknowledge, and react. In addition to past performative political exchanges between Yolngu people and the missionaries such as the 'Adjustment Movement' held on Elcho Island in 1957 (Berndt 2004[1962], also see Morphy 1983), and more recent performative encounters such as the one with then Prime Minister John Howard in 1997 (Magowan 2000:317ff), I would like to include the spectacular ceremony performed by several clans from Yirrkala at the Northern Territory High Court to redress past legal injustices (Murray 2004) as well as numerous less spectacular and formal performances such as welcome ceremonies for politicians and state representatives (McIntosh 2000:55ff; Trudgen 2007), Christian everyday meeting and larger revival gatherings (Magowan 2007b; Slotte 2005), art exhibition openings in urban settings (Mundine 1997), graduation ceremonies to award degrees in education or in theology both in Darwin and in Northeast Arnhem Land communities, community shop and office openings, local and regional sporting events, as well as impromptu farewell performances for non-indigenous teachers - including the anthropologist (Tamisari 2005). ${ }^{5}$

From a performance perspective, as I have elsewhere argued for Australian indigenous art productions and installations (Tamisari 2007b), indigenous festivals in general and indigenous rituals of diplomacy cannot be entirely understood as calculated 'political strategies' (Phipps 2011), nor simply defined political platforms in the narrow sense of the term. Given the many economic, policy, and bureaucratic constraints, together with 'frames of white reception' (Casey 2012) imposed on the organisation of indigenous cultural events (Henry 2008:58; Phipps and Slater 2010:38), as well as the necessity 'to enact the codified understandings' and expectations of white people in order to 'receive positive recognition in the wider Australia' (Hinkson 2013:303,302), festivals and especially the great variety of performances they host are rather performative tactics that take advantage of any opportunity to make announcements and claims, to confront, and to challenge. As tactics in De Certeau's terms, the Gattjirrk Festival performances manoeuvre 'within the enemy's field of vision' and, seizing 'on the wing the possibilities that offer themselves at any given moment', destabilize, take order by surprise, and challenge others (De Certeau 1988[1980]:37).

Started in 1982 as a music event entitled 'Music, Sound and Light Competition', the Milingimbi Festival was renamed 'Gattjirrk Cultural Festival' in 2004, and has been held annually to now. ${ }^{6}$ The event is a product of the social commitment and cultural vision that its artistic director and organiser, Keith Lapulung, has invested in the social-political and educative potential of music since the mid-Seventies after the formation of his rock band 'Black Wizards', now known as 'Wirrinyga Band' (cf. Corn and Gumbula 2005:31). Dunbar-Hall's observations (2006:122) on the song texts of the Wirrinyga Band can equally describe how, since its very beginning, the Festival organisers aim not only at denouncing the problems local youths face in their daily lives but also at celebrating and strengthening fundamental values and practices at the basis of Yolngu presence, persistence, and survival. ${ }^{7}$ Paraphrasing DunbarHall (ibid::123), the Festival deals with individual and community health - physical and moral - education, political collaboration, and reconciliation with the non-indigenous world. While Festival organisers formulate these objectives mainly in terms of a discourse of 'sharing culture' within community groups and outside visitors, youths propose and share their experiences and their version of history through performance.

With reference to the educational purpose of the Festival, it is interesting here to note that the term 'Gattjirrk', chosen in 2004 as the event's new name, is the same adopted by Yolngu teachers in 1993 to refer to the new bicultural program at the Milingimbi Community Education Centre (CEC) $(1991,1993){ }^{8}$ The result of a long, politically directed, process to affirm Yolngu perspectives and autonomous decision-making in education, the Gattjirrk curriculum devel- 
oped in Milingimbi School is a pedagogical program for primary and secondary schooling aimed at promoting and implementing the integration of Yolngu language, local knowledge, values, and principles in compulsory education (Tamisari and Milmilany 2003). Like the curriculum, the Gattjirrk Festival's objective is to define the terms of engagement in order to establish and maintain a reciprocal recognition and balanced exchange with the balanda world, namely the local and Federal Government institutions such as the Northern Territory Board of Studies, the Northern Territory Department of Health, and the East Arnhem Regional Shire.

It is interesting to note the origin and aims of the Garma Festival as it also expands on the notion of sharing from equal power positions as understood in Yolngu law. Likewise stemming from the bicultural programs at Yirrkala School, the term garma refers to an open public ceremonial ground of encounter, exchange, and confrontation, 'an open forum where people can share ideas and everyone can work hard to reach agreement' (Christie and Veran 2014; Marika-Munungiritj 1998). ${ }^{9}$ Further, the notion of Garma conveys the principle of 'balance in knowledge' (Yunupingu and Morphy 2000:493), and 'a true sense of equality' and reciprocity (ibid.:494; Yunupingu 1993, 2004) between the involved parties. In the Garma Festival, these principles that articulate Yolngu power relations are directly transposed from the Yolngu domain to the political negotiation with balanda people and institutions (De Largy Healy 2011).

\section{'SHARING CULTURE' AND TAKING UP RESPONSIBILITY}

In what follows I summarise the letter written by Keith Lapulung in June 2003 to the sponsors requesting financial support for the 2004 event as it concisely states the Gattjirrk Festival's educational and cultural objectives and its overall vision in terms of an encounter with the balanda. Echoing the public speeches, images, metaphors, and the types of performances at the Festival, the letter promotes the strengthening of local solidarity and identity through participation, and insists on the 'sharing of culture' in terms of accepting difference, opening up to change, and facing the difficulties in the encounter with the balanda. ${ }^{10}$ Throughout the years, the event's main sponsor remains the Local Council, now the East Arnhem Regional Council and the Arnhem Land Progress Aboriginal Corporation (ALPA). ${ }^{11}$

The letter starts by noting the Festival's change of name and the growing numbers of participants from Yolngu communities in the region and, for the first time, a wider audience thanks to a live broadcast by TEEABA ${ }^{12}$ throughout the Top End and Western Australia. It then states that 'from the very beginning ... the Festival has always aimed at drawing people together to celebrate and strengthen cultural expressions and promote the physical wellbeing of the community' as well as giving 'an opportunity to older people to encourage the young towards a healthy and active life style and towards taking responsibilities'. In addition, the letter also lists some of the band names who have participated in the 2003 Festival and their commitment to 'the maintenance of a strong culture'. ${ }^{13}$ As I will consider in detail below, the letter also includes a paragraph describing how the new Festival logo visually condenses the event's main objective of being a moment of encounter when different people can share knowledge. The letter concludes stating that despite all the changes throughout the years, it is crucial to maintain and develop the Festival in order 'to promote local solidarity and cultural awareness which nourishes the connection between present circumstances and the living wisdom from the past'.

The Gattjirrk Festival is usually held for three days at the end of October to midNovember and mainly consists of a series of evening music and dance performances. At the events I participated in, each evening would be opened by a Church group performing a few hymns often accompanied by action dancing. ${ }^{14}$ This performance was then often followed by a welcome speech by a Church Elder who would state the gathering's objectives and give a 
blessing (see below). Up to 2005, the evening performances were dominated by the music groups who would take centre stage and play for several hours to a dancing crowd of mainly young children. At times, the music groups were interrupted by short pantomimes describing the dangers of consuming intoxicating substances, playing cards, and behaving in an uncaring and selfish manner. Only on the third and final night of the Festival was there the dance competition between teams of teenagers performing in turns in front of a jury. From the video of the 2013 Gattjirrk Festival I was given in June 2014, I note that the organisation of the festival has slightly changed in the last few years as it involves a higher number of outsiders who provide technical support to the music bands performing on a larger stage built for the occasion on the school ground and includes arts and crafts activities usually located in front of the Milingimbi Arts Centre (http://www.milingimbiart.com/about.html) that re-opened in 2005. Many local volunteers are engaged in cooking and distributing bush food previously hunted as well as performing so-called in English 'cultural dances' drawn from the ceremonial repertoire. ${ }^{15}$ However, despite what seems to be a more efficient organisation involving more people from outside, the Festival structure, atmosphere, and main objectives remain the same.

As in the past and with other entertainment activities, such as Australian rules football matches or informal card gambling, the Festival cannot take place at the same time as mortuary, circumcision, and secret/sacred ceremonies regularly held in the community and in the region. These ceremonies, in fact, require everybody's direct and indirect participation as they articulate power relations at sociocentric and egocentric levels. As a consequence, the Festival dates are fixed at the last minute when all conditions are appropriate and the setting up of the equipment can be completed in a few days of frantic activity. Although the Festival can thus seem to be antithetical to the solemnity and political significance of ceremonies, nevertheless, it reflects the logic of ritual. First of all, as with ceremonies, the Festival offers old people an opportunity to 'encourage the young towards ... taking responsibilities'. It is through ritual performance, in fact, that a young person acquires specific knowledge about countries on which he or she may exercise different rights, learns his/her duties through observation and practice, and masters the subtle ways of expressing this knowledge in order to gain, affirm, or consolidate his/her authority (Christie 1992:12; Tamisari 2000). Albeit in a different way, Festival performances play a crucial role in articulating negotiations and tensions among local groups, between generations within the community as well as with the balanda world by means of different performative tactics. It is interesting to note that ceremonial dancing was also central to the implementation of the Gattjirrk curriculum, because, as for the ceremonies and the Festival, it is a modality of acquiring and testing one's rights and duties throughout the progressive educational stages of one's life (Tamisari and Milmilany 2003). Just as for ceremonies, every festival participant does not only know and learn his/her own role, rights, and duties necessary to organise and coordinate the event in an efficient manner. The Festival also provides each group with the opportunity to display its knowledge, experiences, and vision in unique new syntheses.

In order to show how the Festival brings together younger and older generations' perspectives in the same space, I now turn to describe how organisers and elders convey discourses and images of 'sharing of culture', and how youth performances engage and challenge others both inside and outside the community.

\section{The Festival logo: 'Follow the footprints that lead to the fire ashes'}

As mentioned, the letter to the sponsors includes a paragraph dedicated to explaining the Festival logo that Keith Lapulung designed in 2003 for the Festival to be held the following year. Despite the fact that the logo was only used for the 2004 event, it well conveys the 
Festival's main vision. As the sketch replicating the design illustrates (see fig. 1), the logo represents two crossing paths (as in an ' $\mathrm{X}$ ') along which there are multicoloured footprints converging to its centre that is referred to as the 'charcoal embers' (lirrwi', or ngurrngitj). In one of our conversations, Lapulung explained to me that the footprints represent the different people who participate in the Festival: the young (yawirriny) and the old (ngalapal), the different clan groups (ba:purru) from the region, the various Christian congregations, the Yolngu, and the balanda, while the 'charcoal embers', namely the Festival, are the point of arrival, the moment of encounter. In Lapulung's words:

[The Festival's] objectives are now condensed in the new Festival logo which is inspired by the cultural significance of 'charcoal embers' (lirrwi'). The centre represents the place where our cultural knowledge and power lie and the footprints along the four paths of different colours convey the message that different people can attain that knowledge by meeting and sharing together. The Festival, in fact, stands for the possibility of embracing difference through a recognition of a common ground. It is through dance, song, and other artistic expressions that we can share our culture and through this sharing we consolidate a strong foundation for future generations.

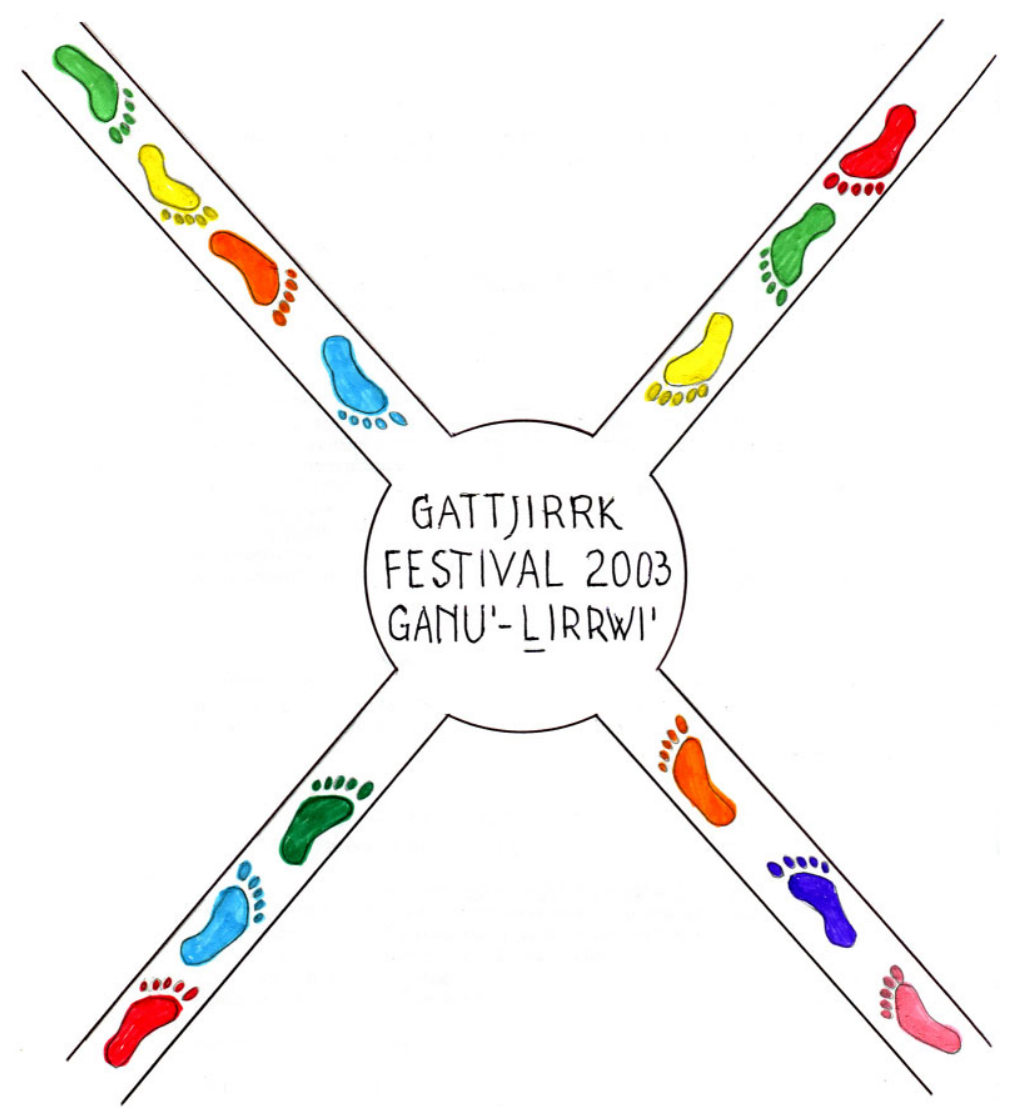

Figure 1: The logo by Keith Lapulung for the 2003 Gattjirrk Cultural Festival taken from the author's fieldnotes, Milingimbi June 2003. 
The fire ashes reference a host of meanings. Located in the front of almost every Yolngu house, the campfire is the centre of a residential group. It is around the hearth that the little great events of daily life take place: children play and adults spend most of the day and night, eat, talk, argue, and receive guests. However, the campfire does not only stand for the sharing of everyday experiences, but, remaining in the same location over the generations, it also connects the living to the deceased relatives who had animated it in the past. Charcoals and ashes are not simply traces left by the 'old people' long gone (worrungu), but they are equated with their knowledge itself that can be picked up by the present generations who sit around the same fire ashes. As Lapulung explained to me to clarify the meaning of the ashes as a point of encounter where knowledge is buried and can be unearthed again:

Well, our knowledge is encountered in the form of the ashes [ganu'] that had been burnt and buried in a fireplace. When you pick up . . that charcoal had been left there by the old people, there is a bit of knowledge that is hidden in those charcoals and buried, and this is like opening a filing cabinet through our knowledge. (Keith Lapulung, Milingimbi, 2 July 2003)

The fire ashes could thus be understood as the pulverised experiences that unite the living to the dead, the present to the past, the ancestors' wisdom to the present time, the old and new generations. For instance, the Yolngu expression 'dha:ra ganu'ngur' (to stand in the fire ashes) is used to refer to a person who connects to, respects, and takes on this knowledge by renewing it in the conviviality of everyday relationships and by transferring it on to the next generation (Tamisari 2007a:153, 2014a). The campfire and the fire ashes are thus not only a symbol of shared cultural values and practices, but a place in which to encounter the Other - both a member of one's residential group and a stranger (mulkurr). And it is a time in which one accepts and is accepted in terms of what one becomes for and with others through a process of what I elsewhere called 'mutual acquaintance', meaning by this an organic process of mutual or personal acquaintance with another person that demands to be lived-in and negotiated with all its possibilities and risks (Tamisari 2006b:27ss). The fire ashes' metaphor used in the Festival logo thus refers to not only the intimate nature of personal relationships in the domestic sphere (Carsten 2000), but also the ways in which each person must be sensitive and open to the other, and, in each encounter, is called to verify and redefine the relationship in which he/she is subjected to the other (De Monticelli 1998:181-2; Tamisari 2006b:30). From this perspective, like the fire ashes, the Festival is a space and time for 'being alongside' (von Sturmer 2001:104) and 'sharing' with others: accepting and confronting the Other's diversity, be they a Yolngu member of one's residential group or a balanda.

The public speeches delivered by Christian leaders at different phases of the Festival elaborate this notion of 'sharing' mainly in terms of the affirmation of each person and group's singularity within an overall discourse of unity and solidarity, or in Lapulung's words cited above, in terms of 'embracing difference through a recognition of a common ground'. The theme of unity and oneness despite groups' and individuals' antagonisms and tensions is central in Christian discourse and is usually expressed in testimonials, speeches, and songs (see Slotte 2005). As an example, I quote the final passage from the speech by the Church Elder who opened the 1992 Festival in Milingimbi:

This entertainment (wakal) is uniting us as a community in God. God is present in spirit to everybody. All people black, white, yellow and red are His children. It is important that tonight we are gathering through this 'entertainment', the balanda come here as well as all the Churches from Northeast Arnhem Land. In our worship 
of God it does not matter the tribe, the colour the language. God knows everything that we are doing. Everyone is alone with God. Young, old, rich and poor. God likes you.

This rhetoric reproduces one of the main principles of Yolngu Law at the basis of political negotiations of land ownership that are expressed in a religious idiom. The network formed by ancestral cosmogonic journeys, and how these are 'reactualised' in ritual, is replete with images and symbols that affirm at once the sameness and difference, autonomy and dependence, singularity and unity of individuals and groups. This principle is expressed by the following Yolngu expressions: 'we join in' (dha:manapanmirr) and 'share' (dha:manar) the same ancestral events, songs, dances, and designs, yet 'we are different', 'we are one and many' (wanggany ga dharrwa), 'together and alone' (rrambangi ga ga:na), 'close and far apart' galki ga barrkuwatj (Tamisari 1998). ${ }^{16}$ However, it is the performances that propose new cultural syntheses or 'performative tactics' with political potentialities. Drawing from de Certeau (1988), a 'tactic' is a game of power that, necessarily played in the enemy's territory - that is, context, categories, and definitions including performance style as determined in specific historical circumstances - takes advantage of any opportunity to announce the singularity and resilience of Yolngu presence, perspective, and becoming in all its complexity. Although non-indigenous people are invited to enter the space of the Festival and be open to learn and be confronted with Yolngu experiences and realities, this space is nevertheless perceived as adjusted to and constrained by balanda values and economic as well as administrative conditions. ${ }^{17}$

In what follows, I will focus on two types of performance always present at these Festivals, namely hip-hop and burlesque dancing and how these styles have been elaborated into a well-rehearsed choreography entitled 'Zorba The Greek Yolngu Style', a real success thanks to the global YouTube circulation, no doubt, another significant example of 'the politics of cross-cultural encounter' (Magowan 2000:309). This is a performance that was not simply geared to educate its different audiences but a tactic because, breaking through the categories, definitions, and order in which it has grown through parody, it provoked the spectators to participate.

\section{HIP-HOP AND BURLESQUE DANCING}

Since the very first edition of the Milingimbi Festival, children, from four to ten years of age, who usually dance individually in the space between the musicians on the stage and the public sitting on the ground, execute a series of frantic movements that make the public roar with laughter. With their back to the public, or with the lower hem of their T-shirts lifted up to cover their faces, all these children bend their knees almost at ninety degrees and shake their bottoms in a circular motion known as 'doitj' or 'shakim'. While this exaggerated single movement is performed by both boys and girls, only the boys repeatedly thrust their pelvis back and forth miming the sexual act. Some performers elaborate the comic aspect of their burlesque dance by inserting a few caricaturised steps and arm movements from the ceremonial repertoire. In these cases, there is even more laughter from the public because these young dancers expose to ridicule what everybody knows to be a most serious dimension of Yolngu political practice mainly found in ritual dancing (bunggul). In the Festival context, the children and the youths are granted a 'licence to joke' (Handelman and Kapferer 1974:484) and within the limited space of the entertainment (wakal), they can ridicule the formal roles, sacred meanings, and foundational values ceremonial dance articulates in the negotiation of political relationships among participating individuals and groups (Tamisari 2000). They do so mainly through 
dancing given that, according to Yolngu educational phases, a great number of Yolngu adolescents can gain full access to dance performance from a very young age, but only a few will have the ability and the opportunities to learn the more specialised training in song performance.

As with all the Festivals I attended, the central and usually the most anticipated part of the 1998 event was the competition of hip-hop dances choreographed by some fifteen groups of adolescents from fourteen to eighteen years of age. To the rhythm of famous techno music of that time, first the girls' groups then the boys performed their original choreographies in front of the public. Each group was composed of a minimum of two to a maximum of four members (with the exception of a male soloist) dressed in the Afro-American hip-hop style fashionable at the time: sneakers, miniskirts, and tight T-shirts for the girls and baggy track suits with hoods for the boys.

While these performances clearly draw from the of breaking or b-boying style dancing developed in the USA (Schloss 2009), the Yolngu interpretation of these dances is more contained, structured, and less improvised than the original model. Both boys and girls prefer the 'more traditional, intricate, and rhythmic' upright dancing characterised by hops, shuffles, cross-stepping, and 'freezes' known as 'toprock' rather than the so called 'power' or 'air moves' performed mainly on the ground by balancing the body on a single hand or spinning on the head (ibid.:13). The rotation of the hips and the shoulder shimmies, the cross stepping, and about turns were performed by the girls with a sort of containment disclosing the shyness that is appropriate and usually displayed in public by young women. Similarly, the steps and arm movement of the boys, that at the time were mainly drawing from Michael Jackson's moves and 'moonwalking', were more spectacular but not as acrobatic as in the breaking style. ${ }^{18}$ In all the Festivals that I have observed, these performances were judged by a jury of three or four elders, who, interpreting the public's response, gave the first three prizes on the basis of the step difficulty, choreographic originality, the performers' energy, synchronisation, and the virtuosity of solo dancers.

If the so-called 'Aboriginal hip-hop' is an urban phenomenon that can be traced back to the formation of some rap groups in the indigenous Sydney suburb of Redfern starting from 1982 (Mitchell 2006:125), Yolngu interpretations of this imported style are not less significative. Although Yolngu adolescents have only recently elaborated their own rap compositions, ${ }^{19}$ the hip-hop dances performed at the Festival similarly represent 'a way of binding communities together through dance and performance', 'a declamatory form of storytelling set to music' (ibid.:136, see also Minestrelli 2014). As with the hip-hop movement more broadly, by being 'designed only . . . by teenagers' for teenagers, Yolngu dance performances are assertions about who their practitioners are and include everything they are interested in: 'music, dancing, sports, vandalism, fashion, various games and pastimes, art, sexuality, the definition of individual and collective identities' (Schloss 2009:11). Further, in the same way in which the urban hip-hop message constitutes a means to express youths' rage towards discrimination by proposing a different perspective on colonial history and affirming their cultural identity (Mitchell 2006:136), Yolngu hip-hop dancers find new ways to deal with, accept, and resist the realities they are facing. By bringing to the fore their experiences as distinct from those of the previous generations, their performances could be seen as new modes of political participation and protest (Minestrelli 2014:142).

\section{'Zorba the Greek Yolngu Style' as tactic of cultural remix}

On 20 September 2007, on the occasion of a local music festival held in Ramingining, one of the Yolngu communities in Northeast Arnhem Land, a group of ten Yolngu teenagers from Elcho Island ${ }^{20}$ presented a short item, a comic dance that made the Yolngu spectators roar with laughter. 
The clay covering the young men's bodies, the red cloth around their loins, and each movement in the 'Zorba the Greek Yolngu Style' dance are citations that refer the audience, both the indigenous local public and the white spectators sitting in front of their computer screens, to precise and well-recognisable pop culture elements as well as ceremonial dance moves in an simple yet energetic choreography. As I described at the beginning of the paper, a wide range of dance styles, sports moves, funny walks, and clownish antics is seamlessly stitched together in a exuberant composition that keeps up with the fast tempo of this disco-beat remix of the famous 'Zorba dance'. ${ }^{21}$ We could say that this is a real process of 'sampling' as used in rap music to the extent that this performance takes moves from several contexts and uses them to compose a different dance: a veritable 'choreographic remix'. I use the term 'remix' here not only to refer to the characteristic way of taking movements from different contexts and integrating them into a new performance, but also in terms of an 'art of remix' ( $c f$. Lashua 2006), or, as I prefer to call it, a 'tactic of remix'. In composing a burlesque choreography seemingly stitching up different aspects of their lives, Yolngu male youths display and forcefully announce their experiences, influences, interests, awareness, and desires in front of the elders and a wider non-indigenous audience.

Elaborated from a specific entertainment genre known as djatpangarri (Corn 2009:12) and comic dances performed during male circumcision ceremonies (De Largy Healy 2013) and also from improvised fun dances described above (shakim or doitj), this dance brings to the fore a host of meanings that are co-produced with particular audiences. On the one hand, as I discussed elsewhere (Tamisari 2010:66), the great quantity of posts by the non-indigenous public following the original video uploaded on YouTube clearly reveals the potentially subversive dimension of this performance. In particular, the comments highlight how this dance mocks stereotypical and racist representations of indigenous people, debunks notions of authenticity, and contests identity construction mainly within the politics of the socio-cultural and moral recognition of indigenous people characterising the country's 'happy hybridity model' of hegemonic multicultural policy ( $c f$. Hage 1998; $c f$. Lo 2000; Tamisari 2008a). On the other, in relation to the local public, 'Zorba the Greek Yolngu style' desecrates the solemnity of dance that, activating ancestral power in combination with song and paintings, demonstrates a person's knowledge and authority at the basis of their affirmation and/or claim of authority and land ownership. In both cases, however, it is the humour and laughter unleashed by the dancers' satirical and ironic choreography that, I argue, transform this dance into a tactic of cultural remix that 'shares culture' locally, nationally, and internationally on its own terms.

This type of burlesque performance is an elaborate instance of a well-established genre of Yolngu 'popular' or 'minor' theatre (djatpangarri) that could be compared with the Italian tradition of 'giullarata', a form of pop/ular farce that takes its name from the jester (giullare), namely the roving minstrels and court fools of the Middle Ages (Fo 1987:109, 1997; Scuderi 2003, 2004:65:276ff). As Lapulung noted while I was reading an earlier draft of this paper to him in June 2014, Yolngu people recognise a similar figure in the 'gabulay', a person who makes others shout, laugh, and whistle by telling stories. As Rakay further explained to me in contrast to the 'songs that make one grieve and worry' (manikay wargumirr), the gubulay teases serious people and things, and is like a clown or a fool (lawalawa) whose funny performances (wakal bunggul) are located in between 'hilarious and serious songs' (wakal ga yuwalk manikay). Like Dario Fo's giullarata, a theatre based on improvised performances including mime, pantomime, clowning, slapstick, obscene gestures, and grotesque movements - the gabulay's burlesque performance is mistakenly 'considered frivolous and aimed solely at making people laugh' (Fo interviewed by Stephanson and Salvioni 1986:163), and it is popular not in the sense of being vulgar and common but, rather, radical and highly political (ibid.:163). As with Fo's popular farces, these short dances are not only subversive both 
locally and nationally, because, as 'a theatre of situation', they bring to the fore 'the conflicts that exist between people (Ballerini and Risso 1978:43)', older and new generations at the community level, as well as between Yolngu and balanda in the politics of representation and recognition (Langton 1993). The gabulay dancer, the Yolngu jester, samples different moves, experiences, and desires of everyday life and puts them together in a hilarious choreography that eliminates the boundary between 'ritual ... and contemporary. ... or popular dance' (Teaiwa 2014:3) and collapses any separation between the past and present, the new and the old, Yolngu and balanda (cf. Deger 2013:357-8). Most importantly, as in ceremony, this performance demands a witnessing: a mutual recognition, involvement, and responsibility to participate and to respond. It is of little importance whether the response is positive or negative, or if the meanings emerging from mainly Yolngu or balanda audiences are co-produced respecting different performance rules. In both cases, spectators are called to witness and to respond. As in Yolngu ritual, the dancers, as jesters, have grabbed everybody's attention, and it is in this ephemeral yet intense moment of mutual resonance that they engender new connections and relationships, or as Lapulung expresses this productivity, they 'can attain ... knowledge by meeting and sharing together'. If as De Largy Healy argues (2011), 'this online hit has changed the Yolngu relation to digital media', and given that digital media has facilitated and broadened the 'politics of sharing culture', I am nevertheless inclined to agree with Deger (2013:369) that '[t]echnological novelty is not the issue'. Rather, by sampling movements from Yolngu ceremonies as well as from the pop culture in which youths are growing up, the dancers produce a composition that articulates 'a mutually enlivening relationship between the new and the old' (ibid.:369): a tactic of cultural remix that, in Lapulung's words (Milingimbi June 2014), by activating 'connections between present circumstances and the living wisdom of the past', offers a way for a generation to react. As I argued elsewhere for ritual (Tamisari 2005:56), the force of performance is in the performance itself, in a 'doing' - that 'special kind of behaving, thinking, relating, and doing' of drama (Schechner 1973:8), the possibility of a here and now of a relationship that accomplishes itself in the event, in the very act of production and reception, in the immediacy and intimacy of participation and accountability, or as the Yolngu would say, in a space and time where people 'share culture'.

\section{CONCLUSIONS}

The Milingimbi Gattjirrk Festival's growing success and the national and international success visibility of the 'Zorba the Greek Yolngu Style' dance should make us reflect on the seriousness of play (wakal) in the study of postcolonial and neo-colonial relations in Australia. However, as Lapulung states in his letter to the sponsors cited above, 'it is through dance, song and other artistic expressions that we can share culture and through this sharing we consolidate a strong foundation for future generations'. I suggest that the Gattjirrk Festival is not only a space to promote solidarity and education, but also a host of creative possibilities or performative tactics where different generations 'share culture' on their own terms. It is in fact by turning attention to dance performances such as the improvised burlesque dancing and its elaboration into the well-conceived and rehearsed 'Zorba The Greek Yolngu Style' choreography that it is possible to start approaching the subtle ways deployed to encounter others. First, this creativity emerges from the plurality of performances - Christian 'action dancing', dances adapted from the ceremonial repertoire, pantomimes, burlesque, and hip hop choreographies - that, staging the realities, experiences and visions of different sections in the community propose new cultural syntheses that coexist and complement each other in any given community. However, the burlesque performances are not only a means by which 
adolescents can express their experiences, but also offer them an opportunity to take up the responsibility of negotiating their social and political position within the intricate network of intergenerational relationships in the community and power relations with the balanda. Thus, I suggest that the Milingimbi Festival is an event that reproduces, often amplifies, and opens towards the outside, the community by means of similar dynamics of participation and responsibility operating in Yolngu ceremonies, and I argue that it is from this perspective that it is necessary to approach its socio-cultural meaning and efficacy. The ambiguity of dance in all its forms offers a means for everybody to adapt to postcolonial circumstances, yet to maintain a degree of social and political autonomy articulated in terms of potential openness and participation in the respect of difference. The organisers' vision and framing of the event - both in their speeches during the Festival and on the recent web site - the image of the logo, and the performances elaborate the notion of 'sharing' in different yet complementary ways. In 'embracing difference throught a recognition of a common ground', the Festival reproduces one of the most complex diplomatic principles of Yolngu Law (rom) in the political relations between groups and individuals: the affirmation of each individual and group's singularity and sovereignty over particular countries within a unitary discourse of connection and solidarity, the respect of every person's autonomy and dignity within the recognition of a mutual interdependence, and the irreducible difference that each person can only claim in relation to being with and for others ( $c f$. Myers 1986:103ff.).

The political potential of these performative tactics reaches its most sophisticated expression in the performance 'Zorba The Greek Yolngu Style'. This dance does not simply negotiate change by dealing with external challenges and 'making sense of the other' (Sweet 1989:63), nor is it only a form of resistance and protest that counter-appropriates western musical, performative, and discursive techniques (Michaels 1989:27). Further, it does not stop at making a strategic use of the mimetic faculty to act on and transform power relations (Redmond 2008; Taussig 1993:250ff). It is rather a tactic because it refuses 'to accord the established order the status of a law, a meaning' (De Certeau 1988[1980]:26) and also because it provides the very opportunity to encounter the Other on an equal standing where a balanced exchange of knowledge can take place. What Yolngu people call 'sharing culture' is thus the performance itself, the singularity of its unfolding in time and space, in the 'secret commerce' between the performer and the spectator and the possibilities it produces (Dufrenne 1973:56). The performative tactic of 'Zorba the Greek Yolngu style', and to a lesser extent, the 2014 touring shows that the now famous group recently renamed 'Djuki Mala' use irony to put the spectator on the spot, and with defiance call the spectator to participate, to acknowledge and to react. ${ }^{22}$ The Yolngu jesters (gabulay) provoke ephemeral yet radical moments of co-presence in which it is possible to encounter or, as Lapulung would say, 'share culture' with others who are open and receptive to taking up the challenge. In their own ways, all Festival performances, and in particular the 'Zorba the Greek Yolngu Style' dance, speak for their own time, thus creating a borderzone where the actors and spectators in the local or virtual community stage the drama of an ever evolving confrontation (Bruner 2005:18; Magowan 2000:317) in which the rules of production and reception are continuously redefined (Myers 1994:679). With this performance, Yolngu adolescents 'seize on the wing' of laughter the brief openness of their Yolngu and balanda spectators and, provoking them to participate, they redefine the notion of 'sharing culture' in terms of a 'reverse' or 'second contact' tracing a 'radically different border' (Taussig 1993:251) between ritual and pop dance, the comic and the serious, the old and the new, Yolngu and balanda. Yolngu burlesque performances demonstrate how play, entertainment, and laughter are key 'performative tactics' in the encounter/contestation with alterity, an intergenerational and cross-cultural space where the creativity of dance is worthy of more attention and in-depth study. 


\section{ACKNOWLEDGEMENTS}

I would like to thank my son (waku) Keith Lapulung for renewing our friendship that over more than twenty-four years has been based on sharing life and ideas. I'm also indebted to Elizabeth Rakay and all my family in Milingimbi who always welcome me to sit around the fire ashes of their hearths. I am also grateful to Sikimeti Ma'u for her help with proofreading.

\section{NOTES}

1. The dance was performed in Ramingining and the original video uploaded on YouTube can be seen at the following link: http://www.youtube.com/watch?v=O-MucVWo-Pw. See also the web site of the dance company recently renamed Djuki Mala: http://www.djukimala.com/ (both web pages were last consulted in June 2015).

2. See the drawing 'Aboriginal Dance' by Mickey of Ulladulla 1862, State Library of New South Wales.

3. Milingimbi is one of the five Yolngu communities in the Northeast Arnhem Land region that extends from Cape Stewart in the West, near Maningrida, and the Koolatong River in the Southeast, near Yirrkala, and includes the settlements of Galuwin'ku (also known as Elcho Island), Gapuwiyak (also known as Lake Evella), Yirrkala, and Ramingining.

4. Equal attention should in fact be given to other dance styles such as 'Christian action dancing' (see note 14), so called 'cultural dances' adapted from the ceremonial repertoire and performed in non-ritual contexts, and disco dancing.

5. The centrality of dance - and the possibilities it creates thanks to its ambiguity - is also well illustrated by 'welcome to country' rituals that are regularly performed at a growing number of formal and informal public events thus occupying the highly and ever contested diplomatic space of belonging and recognition in indigenous and non-indigenous relations (see Everett 2009; Merlan 2014).

6. I attended the festival editions held in 1990, 1991, 1992, 1998, 2000, and 2004. I video-recorded the Festival in 1998, and over the years, I conducted several formal and informal interviews with Keith Lapulung, the Festival's founder and organiser. During my last visit in Milingimbi in June 2014, I was given a video documenting the 2013 edition of the Gatthirrk Festival. The latest edition was held in October 2014. See the web site: https://www.facebook.com/GattjirrkFestival

7. The song collections of the Wirrinyga Banda are: 'Dreamtime Shadows', Central Australia Aboriginal Media Association (CAAMA 1990), 'Dreamtime Wisdom, Modern time Vision', CAAMA 1996.

8. The term 'Gattjirrk' refers to the geographical area in which Milingimbi is located in relation to the Yirrkala region in the 'sunrise' or 'Eastern side' (Miwatj) and Maningrida region in the 'sunset' or 'Western side' (Madhakal) of Northeast Arnhem Land.

9. A culturally dense term, garma, was first used to develop the pilot project 'Garma Maths' leading to the implementation of 'both-ways' education at Yirrkala School in 1986 (Ngurruwuthun 1991).

10. As Lapulung states (pers. comm., 3 June 2014) 'Every year we choose a [festival] name based on community theme'. Significantly, the title of the 2009 Gattjirrk Festival was 'Building Bridges, Connecting Cultures', while the title of the 2013 and 2015 editions was 'Healthy People, Strong Culture, Active Lifestyle' (see Gattjirrk Festival

media release at http://www.eastarnhem.nt.gov.au/storage/latest-news documents/Media_Release_Gattjirrk 17.11.13.pdf, last consulted August 2014).

11. ALPA is an Yolngu-owned organisation that operates retail stores in all main Arnhem Land Communities and supports a series of health, education, and ceremonial activities (http://www.alpa.asn.au/, last consulted April 2015).

12. 'Top End Aboriginal Bush Broadcasting Association' (TEABBA) is a satellite radio network that offers operational support to Remote Indigenous Broadcasting Service (RIBS) in twenty-nine indigenous communities in North Australia. See the web site: http://teabba.com.au/ last consulted August 2014.

13. The music groups include: Wirrinyga Band, Gomu Band, Yalibarki Band, and Djambang Band from Milingimbi and other groups from other communities in the region such as the Dharrwar Band, the Saltwater Band from Galiwin'ku and the Black Iron Band from Ramangining. For a video 'Introducing the Djambang Band', see https://www.youtube.com/watch?v=ViXk1QLHSk0

14. From the 70s when 'action dancing' was developed during the Christian revival movement or the 'Aboriginal Pentecost' across Arnhem Land communities (Gondarra 1993), it has 'become a popular form of Christian expression in the North and Central Australia' (Brady 1989; Magowan 2007a:163). In one or more lines, a group of women usually perform a series of arm movements to Christian hymns in English and local languages played on a tape recorder. While up to the late nineties, these dances were performed by standing still and moving the arms to illustrate some key Christian notions and values such as love, Holy Spirit, repentance, today, they include steps, turns, and hip movements and are performed to a wider range of world music of African, Fijian, and American origin (see Tamisari 2012, unpublished data in preparation).

15. See some photos of the 2013 Festival at: https://www.facebook.com/media/set/?set=a.679687345389371 $.1073741827 .481767318514709 \&$ type $=1$ last consulted June 2015).

16. In ceremony, each group's uniqueness is expressed or concealed in the execution of songs, dances, and designs that can, according to context, emphasise its closeness or distance, unity, or autonomy in relation to other groups by highlighting or eliminating differences in melody, language, narrative, musical structure, dance 
movements, and choreographies (Keen 1994:44 and 149; Morphy 1984:20). In ceremonies, ancestral presence is 're-actualised' in a multimedia mis-en-scene where movement, sound, and naming are recomposed in the visual, poetic, and musical dimensions of performance. Ancestral presence manifests itself in complex synesthesia in which the song text evokes movement rather than sound, the visual becomes musical in the dance, and the music becomes visible in the designs and choreographies (Tamisari 2005:52; on synesthesia in Yolngu ceremonial songs, see Magowan 2001:44-5; Tamisari 2008b, 2014b; see also Feld 1996:92-4).

17. I thank one of the anonymous referees for drawing my attention to the ambiguous nature of the Festival space: a stage where Yolngu people can show their own version of history and reality but remains nevertheless subjected to balanda surveillance.

18. Dance styles known as 'toprock' and 'krumping' have also influenced the dance moves that Yolngu adolescents perform in the local 'disco' usually organised on Saturday nights in Milingimbi community. I was told that this type of style 'that mixes the old and the new fashion of dance' is called djingadhapayunamirr bunggul that, if I am correct in identifying its composing words, can be translated as 'raising the heel dance' (djinga from djingaryun means stand or get up and dhapa heel). The term bunngul refers to dancing as well as the event where dancing takes place.

19. For a rare example of a Yolngu rap, see the composition entitled 'Yolngu Land' (https://www.youtube.com/ watch? $\mathrm{v}=1 \mathrm{YmSld} 2 \mathrm{oHhg}$ ) by Nathan Biyalnga Bidinggal; a more recent track though combined with break dance is 'To the Other Side. Yolngu. Street Boys' (http://vimeo.com/62880892). Both web pages were last consulted in May 2015.

20. Originally, the group of dancers known as 'Moonlight Dancers', and later named 'Chooky Dancers', was composed of Lionel Dulmanawuy, Daren Matan, Jarvin Dhulinyjarra, Aaron Djilmilkinya, Lawrence Lambarr, Gerald Dulanydjun, Nathan Guymungura, Terry Nupurra, Justin Ganapunbun, and Terrance Marrwa.

21. Zorba's dance was originally written by Greek composer Mikis Theodorakis for the film 'Zorba the Greek', directed by Michael Cacoyannis and released in 1964. One of the most well-known symbols of 'Greekness', it is interesting to note that this music was in part the result of Theodorakis' commitment to promote popular music forms (such as the rebetika songs associated with the urban low-life milieu) to create 'a new music "vernacular", one that appealed to a broad audience while making a socio-cultural impact' (Mouyis 2007:26).

22. In establishing a professional indigenous dance company (https://www.facebook.com/djukimala2014) and offering international audiences a representation that reproduces an accepted and expected register of cultural difference, the Djuki Mala's performances have turned into spectacle and lost their subversive edge (Anke Tonnaer, pers. comm., 29 May 2015).

\section{REFERENCES}

BAKHTIN, M. 1984a. Rabelais and His World, trans H. Iswolsky, First Midland Book edn. Bloomington: Indiana University Press.

1984b. Problems of Dostoevsky's Poetics, trans C. Emerson. Minneapolis: University of Minnesota Press.

BALLERINI, L. and G. RISSO. 1978. Fo explains: An interview. The Drama Review 22(1): 33-48.

BERNDT, R. 2004[1962]. An Adjustment Movement in Arnhem Land, Northern Territory Australia. Oceania Monograph 54. Sydney: The University of Sydney.

BRADY, M. 1989. Number one for action. Australian Aboriginal Studies 1: 62-63.

BRUNER, E.M. 2005. Culture On Tour. Ethnographies of Travel. Chicago and London: The University of Chicago Press.

CARSTEN, J. 2000. Introduction. Cultures of relatedness. In J. Carsten (ed) Cultures of Relatedness: New Approaches to the Study of Kinship. Cambridge: Cambridge University Press, pp. 1-36.

CASEY, M. 2012. Colonisation, notion of authenticity and aboriginal Australian performance. Critical Race and Whiteness Studies 8: 1-18. [last consulted June 2015.] http://www.acrawsa.org.au/files/ejournalfiles/ 177CRWS201281Casey.pdf

CHRISTIE, M. 1992. Grounded and Ex-centric Knowledges: Exploring Aboriginal Alternatives to Western Thinking. Paper presented at the Fifth Annual Conference on Thinking. Townsville, James Cook University, 7 July.

CHRISTIE, M. and H. VERAN. 2014. The touch pad body: A generative transcultural digital device interrupting received ideas and practices in aboriginal health. Societies 4(2): 256-264. [last accessed August 2014.] http://www.mdpi.com/2075-4698/4/2/256

CORN, A. 2009. Reflections \& Voices: Exploring the Music of Yothu Yindi with Mandawuy Yunupingu. Sydney: Sydney University Press.

CORN, A. and N. GUMBULA 2005. Ancestral precedent as creative inspiration: The influence of soft sands on popular song composition in Arnhem Land. In G. K Ward and A. Muckle (eds) The Power of Knowledge, the Resonance of Tradition, Electronic publication of papers from the AIATSIS Indigenous Studies conference, September 2001, 31-68, available at http://www.aiatsis.gov.au/_files/research/ Indigenous_studies_conf_2001.pdf (last accessed August 2014).

DE CERTEAU, M. 1988[1980]. The Practice of Everyday Life, trans. S. Rendall. Berkeley: University of California Press.

DE LARGY HEALY, J. 2011. 'Murayana va á Garma cette année!’: Ceremonies publiques et rituels contemporains du nord-est de la Terre d'Arnhem (Australie). Journal de la Société des Océanistes 1: 123-134.

2013. Yolngu Zorba meets Superman. Australian aboriginal people, mediated publicness and the culture of sharing on the internet. Anthrovision (online) 1.1. Online since 01 August 2013, http://anthrovision.revues.org/362 (last accessed August 2014). 
DE MONTICELLI, E. 1998. La conoscenza personale. Introduzione alla fenomenologia. Milano: Guerini Studio. DEGER, J. 2013. The jolt of the new: Making video art in Arnhem Land. Culture, Theory and Critique 54(3): $355-371$.

DESMOND, J. 1993. Embodying difference: Issues in dance and cultural studies. Cultural Critique 26: $33-$ 63.

DUFRENNE, M. 1973. The Phenomenology of Aesthetic Experience, trans. E. L. Casey. Evanston: Northwestern University Press.

DUNBAR-HALL, P. 2006. 'We have survived': Popular music as a representation of Australian aboriginal cultural loss and reclamation. In I. Peddie (ed) The Resisting Muse: Popular Music and Social Protest. Burlington: Ashgate Publishing Company, pp. 119-131.

EVERETT, K. 2009. Welcome to country ... not. Oceania; A Journal Devoted to the Study of the Native Peoples of Australia, New Guinea, and the Islands of the Pacific 79(1): 53-64.

FELD, S. 1996. Waterfalls of song. An acoustemology of place resounding in Bosavi, Papua New Guinea. In S. Feld and K. Basso (eds) Senses of Place. Santa Fe: School of American Research Press, pp. 90-135.

FO, D. 1987. Manuale minimo dell'attore. Torino: Einaudi.

1997. Contra Jogulatores Obloquentes, Against Jesters Who Defame and Insult. Nobel Prize Lecture, 7 December 1997 (available at http://www.nobelprize.org/nobel_prizes/literature/laureates/1997/fo-lecture-i.html, last accessed August 2014).

GIBSON, C. and J. CONNELL. 2011. Festival Places. Revitalising Rural Australia. Bristol, Buffalo, Toronto: Channel View Publications.

GLOWCZEWSKI, B. 2007. Introduction. Entre spectacle et politique: les singularités autochtones, Le défi indigène. Entre spectacle et politique, Montreuil: Aux Lieux d'Être, pp.11-35.

GONDARRA, D. 1993. Pentecost in Arnhem Land, Australia. Renewal Journal 93(1): 13-16. Brisbane: Australia. HAGE, G. 1998. White Nation. Fantasises of White Supremacy in a Multicultural Society. Sydney: Pluto Press.

HANDELMAN, D. and B. KAPFERER. 1974. Forms of joking activity: A comparative approach. American Anthropologist 74(3): 484-517.

HENRY, R. 2000a. Dancing into being. The Tjapukai aboriginal cultural park and the laura dance festival. The Australian Journal of Anthropology 11(3): 322-332.

2000b. Festivals. In S. Kleinert and M. Neale (eds) The Oxford Companion to Aboriginal Art and Culture. Oxford: Oxford University Press, pp. 586-587.

2008. Engaging with history by performing tradition. In J. Kapferer (ed) The State and the Arts: Articulating Power and Subversion. New York: Berghahn, pp. 52-69.

2011. Dancing diplomacy. Performance and the politics of protocol in Australia. In E. Hviding and K. Rio (eds) Made in Oceania. Social Movement, Cultural Heritage and the State in the Pacific. Wantage: Sean Kingston Publishing, pp. 180-193.

HINKSON, M. 2013. Back to the future: Warlpiri encounters with drawings, country and others in the digital age. Culture, Theory and Critique 54(3): 301-317.

KEEN, I. 1994. Knowledge and Secrecy in an Aboriginal Religion. Oxford: Clarendon Press.

LANGTON, M. 1993. 'Well I heard it on the Radio and I Saw it on the Television. ..'. An Essay for the Australian Film Commission on the Politics and Aesthetics of Filmmaking by and about Aboriginal People and Things. Sydney, Australian Film Commission.

LASHUA, B. 2006. The Arts of the Remix: Ethnography and Rap. Anthropology Matters, available on line: http://www.anthropologymatters.com/index.php/anth_matters/article/view/67 (last accessed August 2014).

LO, J. 2000. Beyond happy hybridity: Performing Asian-Australian identities. In I. Ang, I. S. Chalmers, L. Law and M. Thomas (eds) Alter/Asians. Sydney: Pluto Press, pp. 152-168.

MAGOWAN, F. 2000. Dancing with a difference: Reconfiguring the poetic politics of aboriginal ritual as national spectacle. The Australian Journal of Anthropology 11(3): 308-321.

2001. Shadows of song: Exploring research and performance strategies in Yolngu women's crying-songs. Oceania; A Journal Devoted to the Study of the Native Peoples of Australia, New Guinea, and the Islands of the Pacific 72(2): 89-104.

2007a. Melodies of Mourning. Music, Emotion in Northern Australia. Crawley: University of Western Australia Press.

2007b. Globalisation and indigenous christianity: Translocal sentiments in Australian aboriginal christian songs. Identities. Global Studies in Cutlure and Power 14(4): 459-483.

MARIKA-MUNUNGIRITJ, R. 1998. The Wentworth Lecture, AIATSIS, available at http://www.aiatsis.gov.au/_files/ events/wentworth/lectures/a318678_a.pdf (last accessed in August 2014).

MCINTOSH, I. 2000. Aboriginal Reconciliation and The Dreaming. Warramiri Yolngu and the Quest for Equality. Boston: Allyn \& Bacon.

MERLAN, F. 2014. Recent rituals of indigenous recognition in Australia: Welcome to country. American Anthropologist 116(2): 296-309.

MICHAELS, E. 1989. Postmodernism, Appropriation and Western Desert Acrylics. Postmodernism: a Consideration of Appropriation of Aboriginal Imagery (Forum Papers), Brisbane: S. Cramer.

MILINGIMBI COMMUNITY EDUCATION CENTRE (CEC). 1991. Dhanarangala Murrurinytji Gaywanangala $(D M G)$ :Thematic approach for both-ways education planning at Milingimbi. Unpublished report, Milingimbi Literature Production Centre, Milingimbi.

1993. Gattjirrk Curriculum Project 1993. Unpublished report, Milingimbi Literature Production Centre, Milingimbi. 
MINESTRELLI, C. 2014. Are we there yet? The political power of 'aboriginal hip-hop' in Australia. In B. Porfilio, D. Roychoudhury, and L. Gardner (eds) See You at the Crossroads: Hip Hop Scholarship at the Intersections: Dialectical Harmony, Ethics, Aesthetics, and Panoply of Voices. Rottherdam: Sense Publishers, pp. $129-146$.

MITCHELL, T. 2006. Blackfellas rapping, breaking and writing: A short history of aboriginal hip-hop. Aboriginal History 30(1): 124-137.

MORPHY, H. 1983. 'Now You Understand'. An analysis of the way Yolngu have used sacred knowledge to retain their autonomy. In N. Peterson and M. Langton (eds) Aborigines, Land and Land Rights. Canberra: Australian Institute of Aboriginal Studies, pp. 110-133.

1984. Journey to the Crocodile's Nest. Monograph accompanying the film Madarrpa Funeral at Gurka'wuy, Canberra: Australian Institute of Aboriginal Studies.

MOUYIS, A. 2007. Mikis Theodorakis and the Articulation of Modern Greek Identity. Unpublished Master Thesis. Johannesburg: University of the Witwatersrand.

MUNDINE, D. 1997. Knowing when to say olé. Periphery Magazine, 13-15 March.

MURRAY, R. 2004. Dhakiyarr vs the King, Videorecording, Sydney, ABC.

MYERS, F. 1986. Pintupi Country Pintupi Self. Sentiment, Place, and Politics Among Western Desert Aborigines. Berkeley: University of California Press.

1994. Culture-making: Performing aboriginality at the Asia society gallery. American Ethnologist 21(4): 79699.

NGURRUWUTHUN, D. 1991. The Garma project. In B. Wei, D. Nayin, Y. Rom and N. Nginingawula, Ngawarranungurumagi (eds) Aboriginal Pedagogy: Aboriginal Teachers Speak Out. Deakin: Deakin University Press, pp. 107-122.

PHIPPS, P. 2011. Performing culture as political strategies: The Garma Festival, Northeast Arnhem Land. In C. Gibson and J. Connell (eds) Festival Places. Revitalising Rural Australia. Bristol, Buffalo, Toronto: Channel View Publications, pp. 109-122.

PHIPPS, P. and L. SLATER 2010. Indigenous Cultural Festivals. Evaluating Impact on Community Health and Wellbeing. A report to the Telstra Foundation on research on Indigenous festivals 2007-2010. Melbourne: Globalism Research Centre, RMIT University.

REDMOND, A. 2008. Captain cook meets general macarthur in the Northern Kimberley: Humour and ritual in and indigenous Australian life-world. Anthropological Forum 18(3): 255-270.

SCHECHNER, R. 1973. Essays on Performance Theory 1970-1976. New York: Drama Book Specialists.

SCHLOSS, J.G. 2009. Foundation: B-Boys, B-Girls, and Hip-Hop Culture in New York. New York: Oxford University Press.

SCUDERI, A. 2003. Unmasking the Holy Jester Dario Fo. Theatre Journal 55(2): 275-290.

2004. The cooked and the raw: Zoomorphic symbolism in Dario Fo's 'Giullarate'. The Modern Language Review 99(1): 65-76.

SLATER, L. 2007. My island home is waiting for me: The dreaming Festival and Archipelago Australia. Continuum: Journal of Media and Cultural Studies 21(4): 571-581.

SLOTTE, I. 2005. Rally at raminging. The 'Uniting' force of music and dance in a Yolngu christian context. In F. Magowan and K. Neuenfeldt (eds) Landscapes of Indigenous Performance. Music Song and Dance of The Torres Strait and Arnhem Land. Canberra: Aboriginal Studies Press, pp. 76-95.

STEPHANSON, A. and D. SALVIONI. 1986. A short interview with Dario Fo. Social Text 16: 162-167.

SWEET, J. 1989. Burlesquing 'The Other' in Pueblo performance. Annals of Tourism Research 16: 62-75.

TAMISARI, F. 1998. Body, vision and movement. In the footprints of the ancestors. Oceania; A Journal Devoted to the Study of the Native Peoples of Australia, New Guinea, and the Islands of the Pacific 68(4): 249-270.

2000. The meaning of the steps is in between, dancing and the curse of compliments. The Politics of Dance, Special Issue. The Australian Journal of Anthropology 11(3): 36-48.

2005. Responsibility of performance. The interweaving of politics and aesthetics in intercultural contexts. In F. Dussart (ed.), Special Issue. Visual Anthropology Review 21(1-2): 47-62.

2006a. Performance come 'fare': Contro-appropriazione e resistenza nell'arte indigena australiana. In M. Ciminelli (ed) La negoziazione delle appartenenze. Arte, identita' e proprieta' culturale nel terzo e quarto mondo. Milano: Franco Angeli, pp. 115-129.

2006b. Personal acquaintance: Essential individuality and the possibilities of encounters. In T. Lea, E. Kowal, and G. Cowlishaw (eds) Provoking Ideas: Critical Indigenous Studies. Darwin: Darwin University Press, pp. $17-36$.

2007a. La logica del sentire nella ricerca sul campo. Verso una fenomenologia dell'incontro antropologico. Molimo 2: $139-162$.

2007b. The art of the encounter: The cheek, drama and subterfuge of performative tactics. In L. Strivay and G. Le Roux (eds) La Revanche de Genres, Art Contemporain Australien. Paris: Ainu Production, pp. 3853.

2008a. I limiti del riconoscimento delle popolazioni indigene australiane. La politica del sentimento e la costruzione della volontà nazionale Australiana. In L. Zagato (ed) Le identità culturali nei nuovi strumenti UNESCO: un approccio nuovo alla costruzione della pace? Padova: CEDAM, pp. 219-245.

2008b. L'atto di nominare e il potere morfopoietico dei nomi e dei toponimi nella cosmogonia yolngu, Terra di Arnhem nordorientale, Australia. Quaderni di Semantica XXIX(2): 231-254.

2010. Dancing for strangers. Zorba the Greek Yolngu Style. A giullarata by the Chooky Dancers of Elcho Island. In A. Tonnaer, F. Tamsiari \& E. Venbrux (eds) Special Issue Indigenous Tourism, Performance, and Cross-Cultural Understanding in the Pacific. La Ricerca Folklorica 61: 61-72. 
2014a. Feeling, motion, and attention in the display of emotions in Yolngu law, song, and dance performance. Journal for the Anthropological Study of Human Movement (JASHM) 21(2): 1-17. http:// jashm.press.illinois.edu/21.2/tamisari.html

2014b. 'Sitting around the fire ashes'. An epistemology of personal acquaintance. Australian Aboriginal Anthropology Today: Critical Perspectives from Europe 'Les actes', http://actesbranly.revues.org/522 (last consulted June 2015)

TAMISARI, F. and E. MILMILANY. 2003. Dhinthun Wayawu. Looking for a pathway to knowledge. The Australian Journal of Aboriginal Education 32: 1-10.

TAUSSIG, M. 1993. Mimesis and Alterity. A Particular Hisptry of the Senses. New York: Routledge.

TEAIWA, K.M. 2014. Culture moves? the festival of Pacific arts and dance remix in Oceania. Dance Research Aotearoa 2: 2-19.

TONNAER, A. 2007. La Dance de l'Avion. Réarticuler les relations de genres au festival de Borroloola. In B. Glowczewski and R. Henry (eds) Le défi indigene. Monttreuil: Aux Lieux d'Être, pp. 89-102.

TRUDGEN, T. 2007. Yolngu Government: Investigating Regional Mechanisms For the Maintenance and Change of Yolngu Law, BA Hon. Thesis. Brisbane: University of Queensland.

TURNER, V. 1967. The Forest of Symbols. Aspects of Ndembu Ritual. Ithaca and London: Cornell University Press. VON STURMER, JOHN. 2001. Hot diggidy dog or stomaching the truth or one-way passage. UTS Review 7(1): 96-105.

WILD, S. 1986. Rom: An Aboriginal Ritual of Diplomacy. Canberra: Australian Institute of Aboriginal Studies.

YUNUPINGU, M. 1993. Yothu Yindi - Finding balance. In H. Semmler (ed) Voices from the Land. Sydney: ABC Books, pp. 1-11.

2004. Interview with George Negus, George Negus Tonight, available at Broadcast 6.30pm on 08/07/2004 http://www.abc.net.au/gnt/profiles/Transcripts/s1150380.htm (last consulted August 2014).

YUNUPINGU, M. and H. MORPHY. 2000. A balance in knowledge: Respecting difference. In S. Kleinert and M. Neale (eds) The Oxford Companion to Aboriginal Art and Culture. Melbourne: Oxford University Press, pp. 493-496. 